\title{
Geospatial model of organophosphate insecticide residues in shallot land in Wanasari Sub-district, Brebes Regency, Central Java Province, Indonesia
}

\author{
Indratin $^{1,5 *}$, Mochamad Arief Budihardjo ${ }^{1,2}$, Muhammad $\mathrm{Helmi}^{1,3,4}$ \\ ${ }^{1}$ Master Program of Environmental Science, School of Postgraduate Studies, Diponegoro University, \\ Semarang - Indonesia \\ ${ }^{2}$ Departement of Environmental Engineering, Diponegoro University, Semarang-Indonesia \\ ${ }^{3}$ Oceanography Department, Faculty of Fisheries and Marine Sciences, Diponegoro University, \\ Semarang-Indonesia \\ ${ }^{4}$ Center of Coastal Rehabilitation and Disaster Mitigation Studies (CoREM), Diponegoro \\ University, Semarang-Indonesia \\ ${ }^{5}$ Indonesian Agricultural Environment Research Institute (IAERI), Agriculture Agency of Indonesia
}

\begin{abstract}
Organophosphates are a group of chemicals that are still allowed to be used in Indonesia and much preferred by most farmers. Excessive usage of organophosphate is expected to contaminate the soil, water, plants, the environment and humans. This research was aimed to create the geospatial models of organophosphate insecticide residues which consist of Chlorpyrifos, Diazinon and Profenofos on farms of shallots production centers. The research was performed in the field of shallots production agriculture in Wanasari sub-district, Brebes Regency in March-June 2020. The extraction of multiresidue pesticides method used was the QuECheRS and the measurement of residues used the 2014 GC Shimadzu with Electron Capture Detector (ECD) which was carried out in the IAERI Laboratory. Meanwhile, the geospatial modeling of organophosphate insecticide residues was done by using the Spline Interpolation method in ArcGIS 10.4, which was carried out in Diponegoro University's CoREM laboratory. The analysis of soil samples taken from 44 sampling points showed that the Organophosphate insecticide Chlorpyrifos was at the level of $<$ LoD- $0.0949 \mathrm{mg} / \mathrm{kg}$, Diazinon found at the level of $<$ LoD-28.1732 $\mathrm{mg} / \mathrm{kg}$, and Profenofos was at the level of $<$ LoD- $0,0919 \mathrm{mg} / \mathrm{kg}$.
\end{abstract}

Keywords. organophosphate, geospatial model, shallot field, Wanasari

\footnotetext{
* Corresponding author: indratin.99@gmail.com
} 


\section{Introduction}

It is widely known that shallot is one of Indonesia's horticultural crop which has high economic value. In 2018, the top five seasonal vegetable commodities with the highest production number in sequence are shallots, cabbage, bird's eye chili pepper, potatoes, and chili pepper. The total national production of shallots reached 1.5 million tons, while cabbage and bird's eye chili pepper reached 1.41 million tons and 1.34 million tons respectively, potatoes as the fourth most produced commodity reached 1.28 million tons, and chili pepper production reached 1.21 million tons. In addition, the pproduction of shallots, bird's eye chili pepper, and potatoes in 2018 has increased compared to 2017 [1]. Shallots are the leading agricultural commodity in Brebes Regency. Data shows an increase in production of shallots in Brebes Regency, from 3,112,960 quintal in 2015 to 3,386,832 quintals in 2016. In 2017, 476,337 tons shallot output in Central Java contributed $32 \%$ of the country's shallot output. Brebes itself produced $18.5 \%$ of the national shallot output and $57 \%$ of Central Java's shallot output [2,3]. Shallots are known to be vulnerable to pests and diseases. The increased production of shallot is linked to the high use of pesticides which prevent crop failure. Wanasari Sub-District in Brebes Regency is one of the sub-districts which have large harvesting area and high shallot production. Yet, it is also classified to have high usage of pesticides. The harvesting area and shallot production in Wanasari SubDistrict, Brebes Regency from 2013 to 2017 successively are 6.17 ha of harvested area, 811,670 quintals of production, in 2014, it was reported the harvested area of 7.07 ha and production of 1,025,680 quintals, 6.59 ha of harvested area and 68,960 quintals of production in 2015, the harvested area of 8.67 ha and the production reached 906,750 quintals in 2016, in 2017, 7.09 ha of harvested area and 587,900 quintals of production are reported [3].

The increased shallot production in Wanasari Sub-district, Brebes Regency continues to occur along with the increasing needs of consumers. The use of pesticides is often applied to agricultural land to increase the crop productivity. The long-term effects of pesticides usage which tend to accumulate can contaminate the soil. Since then, there are official regulations limiting the use of organochlorine pesticides [4]. Organophosphate, carbamate and peritroid insecticides began to be used in 1970 [5]. The use of pesticides could cause negative impact in which the residue left on the soil and agricultural products to its processed products can pollute the the environment and cause disturbance to the ecosystem[6]. The use of pesticides from the Organochlorine, Organophosphate, and Carbamate groups is revealed to have polluted the paddy fields in Central Java [7]. Pesticide residues are also reported to have polluted the agroecosystems of food crops such as soybeans and vegetable crops.

There are 317 samples of agricultural soil collected from the European Union revealed that there were more than $80 \%$ of the tested soil detected 1 or more pesticide residues and $58 \%$ contained a mixture of residues, there were 4- 6 mixed of pesticide residues and even more than 10 mixed of pesticide residues [8]. The soil sample from the cocoa plantation area in the West Dormaa of the Brong Ahafo region in Ghana detected some organophosphates namely chlorpyrifos, profenophos and pyrimiphos-methyl, whereas in the water samples, there were chlorpyrifos, diazinon and pyrimiphos-methyl [9]. The soil samples in Sraban, Bantul, Yogyakarta, organophosphate residual levels exceed MRL (Maximum Residue Limit) with residual levels of $0.0573 \mathrm{ppm}$ (MRL levels of 0.05 ppm)[10]. The blood of rice farmers in Indramayu Regency, West Java, Indonesia showed that there were residues of Organophosphate Malation, Profenofos, Diazinon, Parathion, Fenitrotion, Difekonazole, Klorfirifos, Metidation [11]. 
A total of seven active ingredients of organophosphate pesticide residues found in soil samples on shallot farmland in Wanasari Sub-district, Brebes Regency, Indonesia including chlorpyrifos, Diazinon, Phenitrotion, Metidation, Malation, Paration, and Profenofos [12], in Kersana Sub-district and Wanasari Sub-district, Brebes Regency, Indonesia, Diazinon, Fenitrotion, Metidation, Malation, Paration were found [13]. The aim of this study is to determine the geospatial model of organophosphate insecticide residues including Chlorphyriphos, Diazinon and Profenofos in the production center agricultural land of shallot in Wanasari sub-district, Brebes Regency, Central Java Province, Indonesia.

\section{Materials and methods}

\subsection{Study area and sampling}

The process of soil sampling at coordinate points determined randomly by using ArcGIS 10.4 software in which it is outlined in the work map. 44 soil samples were taken from Jagallempeni Village, Glonggong Village, Tanjungsari Village, Sisalam Village, Lengkong Village, Sidamulya Village, Wanasari District. In order to determine the coordinate points in the field using GPS (Global Positioning System) Garmin 62sc. The soil sampling was carried out in March-June 2020. It was carried out in a composite manner using a soil drill. Each sample was acquired from 5 sub-sample points, with a distance between subtypes around $30-50 \mathrm{~m}$. The soil samples were acquired by using a soil drill at a depth of 0-20 cm in tillage layer [14]. The soil samples taken from 5 sub-samples were made into one place, in a plastic bag and given the identity of the sample number of Village and Sub-District names to be then taken to the laboratory for analysis.

\subsection{Multiresidue extraction using QuEChERS method}

The QuEChERS method is the latest method developed to extract pesticide residue content in a sample. This method prioritizes the principle of analysis that is Quick, Easy, Cheap, Effective Rugged, and Safe. The procedures of using QuEChERS method are done by weighing a sample (soil, plants) of 10 grams, and then put it in a teflon bottle or glass bottle with a volume of $50 \mathrm{ml}$. After that, add $10 \mathrm{ml}$ of aceton p.a or acetonitrile p.a. and then the solution is shaken for one minute until homogeneous. Next, add 4 grams of Magnesium sulfate $\left(\mathrm{MgSO}_{4}\right)$ anhydrous or can be replaced with anhydrous Sodium sulfate $\left(\mathrm{NaSO}_{4}\right)$ and 1 gram of Sodium chloride $(\mathrm{NaCl})$. The solution was then centrifuged for 2 minutes at 3000 rpm. The results are filtered with filter paper that has been coated with anhydrous $\mathrm{MgSO}_{4}$ or $\mathrm{NaSO}_{4}$ powder, and the extractant is collected in a $10 \mathrm{ml}$ volume test tube. Rinse the filter paper with acetone p.a until the extractant volume reaches $5 \mathrm{ml}$ then injected into the GC instrument for organophosphate analysis [15].

\subsection{Analysis of organophosphate residues}

Analysis of organophosphate pesticide residues including Diazinon, Chorphyrifos, Profenofos, Malathion, Parathion and Phenitrotion was performed at the Laboratory of IAERI in Pati, Central Java, Indonesia using the 2014 Electron Capture Detector (ECD) for Shimadzu Gas Chromatography. The determination of Diazinon, Profenofos, and Chlorpyrifos content in the soil, using multiresidue pesticide analysis method based on standard methods of the Directorate General of Crops and the Directorate General of Plant Protection (2006). 
The GC conditions are as follows:Make Up and Carrier Gas: N2UHP Gas Detector: Electron Capture Detector (ECD), Inner diameter $0.25 \mathrm{~mm}$ ID, Flow Rate (Make Up Flow): $22 \mathrm{~mL} / \mathrm{minute}$, Column Flow: $0.5 \mathrm{~mL} / \mathrm{min}$, Column: Rtx-5 length $30 \mathrm{~m}$, Detector Temperature: $300^{\circ} \mathrm{C}$, Injection Temperature: $250^{\circ} \mathrm{C}$, Programmed Oven Temperature: $150^{\circ} \mathrm{C}$. The content of insecticide residues in soil samples is calculated using the formula of the Pesticide Commission [16].

Information:

$$
\text { Residue }(\mathrm{mg} / \mathrm{kg})=\mathrm{A} \frac{\mathrm{C}}{\mathrm{B}} \times \frac{\mathrm{D}}{\mathrm{E}} \mathrm{x} \frac{\mathrm{F}}{\mathrm{G}}
$$

$\mathrm{A}=$ standard solution concentration $(\mu \mathrm{g} / \mathrm{mL})$

$\mathrm{B}=$ standard peak area (reading data from $\mathrm{GC}$ tools)

$\mathrm{C}=$ peak area of sample (reading data from GC tools)

$\mathrm{D}=$ standard solution injected volume $(\mu \mathrm{L})$

$\mathrm{E}=$ injected sample solution volume $(\mu \mathrm{L})$

$\mathrm{F}=$ volume of dilution $(\mathrm{mL})$

$\mathrm{G}=$ initial sample weight $(\mathrm{g})$

\subsection{Geospatial modeling}

Geospatial analysis technique has recently been used in various researches from different fields. Not only used by geographers, but also other researchers from mixed areas have been using this technique. This technique can be used by oceanographers to create preservation zone map by incorporating the marine biodiversity's preservation areas, or coastal blue carbon ecosystems [17,18]. In addition, geospatial modeling can also be applied in producing tsunami vulnerability index map, earthquake capacity assessment, urban growth and also ecotourism activities [19-22]. Spatial analysis method can also be and combined with other methods of analysis such as Hierarchical Component Analysis (HCA) and Principal Component Analysis (PCA) to later be called multivariate statistical analysis [23]. Since this technique is demonstrated to be flexible and effective in various fields, this research used this technique to create the geospatial modeling of organophosphate. One of the prominent tools in the mapping process of geospatial modeling can also be done by using remote sensing from satellite platform [24]. However, in this research, the organophosphate residual data taken from the coordinate points are tabulated using Microsoft Excel and transformed into a mapping system using ArcGIS 10.4. Indonesia does not yet have a standard organophosphate residue allowance in the soil, so the use of MRLs (Maximum Residue Limits) in the soil uses MRLs approach to plant products. The MRLs applied in this research is presented in Table 1.

Table 1. Reference in determining MRL of Organophosphate residues in shallots (root vegetables)

\begin{tabular}{|c|c|c|c|}
\hline No & $\begin{array}{c}\text { Type of } \\
\text { Organophosphate }\end{array}$ & $\begin{array}{c}\text { MRLs } \\
(\mathrm{mg} / \mathrm{kg})^{*}\end{array}$ & Reference \\
\hline 1 & Diazinon & 0,05 & \multirow{3}{*}{$\begin{array}{l}\text { * Maximum Residue Limits of } \\
\text { Pesticide on Agricultural } \\
\text { Products 2008. SNI } \\
7313: 2008[25]\end{array}$} \\
\hline 2 & Chlorpyrifos & 0,2 & \\
\hline 3 & Profenofos & 0,05 & \\
\hline
\end{tabular}


Referring to the MRLs level, the level of organophosphate residual contamination of the geospatial model is divided into five categories, namely: very low, low, medium, high, and very high. The MRLs number for each type of organophosphate is the lowest number of the high category limit, with the division of ranges for each category as follows:

(1) very low category ( $<$ LoD-limit of detecion),

(2) the MRLs value minus the value of LoD is divided into two categories of low and medium categories,

(3) the high category between MRLs is added to the result of the distribution of the range values from point 2 , and

(4) the very high category is greater than the high category value.

The geospatial modeling of organophosphate insecticide residue is done by putting the residual data in ArcGIS software version 10.4 spline Interpolation model. The ArcGIS software is known to be essential in determining various geographic information both in land and water areas, such as coastal length, extent of abrasion, shoreline changes [26]. The best methods used for the result differences of the interpolation process of the DEM (Digital Equivalent Model) are the Natural Neighbor interpolation method and the regularized spline [27]. In calculating the data taken from dryland such as farmland, DEM is known to be important [28]. Moreover, the interpolation method is best used since it can cover the restricted soil types portrayal by differentiate the soil sampling [29]. The different soil surfaces is stated to be able to create better outcome when it is done using the spline method [30]. The delineation is based on the results of the analysis with five categories: very low, low, medium, high and very high with different colors.

The spatial model of the organophosphate insecticide residue consists of the spatial model of each type of Chlorpyrifos, Diazinon and Profenofos. The results of making geospatial models using the spline interpolatin model are formed as a basis for analyzing organophosphate residual contamination analysis. By looking at the geospatial model, can be used to predict which areas are very low, low, medium, high and very high, with different color indicators from five types of pollution categories.

\section{Results and discussions}

\subsection{Organophosphate insecticide residues in soil}

The samples of shallot farmland in Wanasari Sub-district of Brebes Regency from 44 sample points were identified as containing organophosphate residues namely chlorophyphos, Diazinon and Profenofos. Chlorpyrifos residues detected $<$ LoD-0.0449 $\mathrm{mg} / \mathrm{kg}$, Diazinon residues $<$ LoD-28.1732 mg/kg, Profenofos residues $<$ LoD- $0.1059 \mathrm{mg} / \mathrm{kg}$. LoD (limit of detection) value is the ability of the GC tool to detect the lowest value that can be read by the GC tool. The LoD of residual chlorpyrifos is $0.0022 \mathrm{mg} / \mathrm{kg}$, LoD of Diazinon is $0.0028 \mathrm{mg} / \mathrm{kg}$, and LoD of Profenofos is $0.0027 \mathrm{mg} / \mathrm{kg}$. The data of Chlorpyrifos residue distribution from all soil sampling points is still under the MRLs (Maximum Residue Limits) value which is the allowed value based on the regulations. However, it must remain vigilant because a little residual increase can pollute the environment at any time. MRLs of Chlorpyrifos residue is $0.2 \mathrm{mg} / \mathrm{kg}$, MRLs of Diazinon residue is $0.05 \mathrm{mg} / \mathrm{kg}$, and MRLs of Profenofos residue is $0.05 \mathrm{mg} / \mathrm{kg}$. Based on the data obtained from the results of laboratory analysis that the Diazinon and Profenofos residues partly exceed the MRLs value. 


\subsection{Geospatial models of Organophosphate residues}

The Geospatial models of organophosphate residual contamination with spline interpolatin include chlorpyrifos, Diazinon and Profenofos residues which can be seen in Figure 1, Figure 2 and Figure 3. These Geospatial Models are categorized into 5 different categories, the dark green color shows the very low categories, the light green color is the low categories, medium categories is represented by yellow color, the orange color indicates the high category and the red color indicates the very high category. Figure 1 shows the distribution of Chlorpyrifos in the very low category $(<$ LoD) spread over 26 sampling points and low category spread at 18 sampling points in some of the locations that became the test sample, in some part of Sidamulya, Jagallempeni, Tanjungsari, Tegalgandu villages, Wanasari Sub-district, Brebes Regency, Indonesia. The distribution of Chlorpyrifos of medium, high and very high categories was not found in Wanasari Subdistrict. The land on shallot farmland in Wanasari sub-district is still under MRsL. The distribution of very high Diazinon values identified in Sidamulya village ranged from $>0.0736 \mathrm{mg} / \mathrm{kg}-28.1732 \mathrm{mg} / \mathrm{kg}$ ). This can occur with excessive use of pesticides, inappropriate dosages or when testing soil samples was taken not long after the application of pesticides. Other researchers have found chlorpyrifos residues above MRLs in Kersana Sub-district (0.222 ppm and $0.278 \mathrm{ppm})$, in Wanasari $(0.555 \mathrm{ppm})$ [13]. Figure 2 shows the distribution of Diazinon residues, identified as having very low $(<$ LoD) 10 sampling points, very high there were 34 points found, for the low, medium and high categories were not found. Other researchers found the Diazinon residue was still under the MRLs [13].

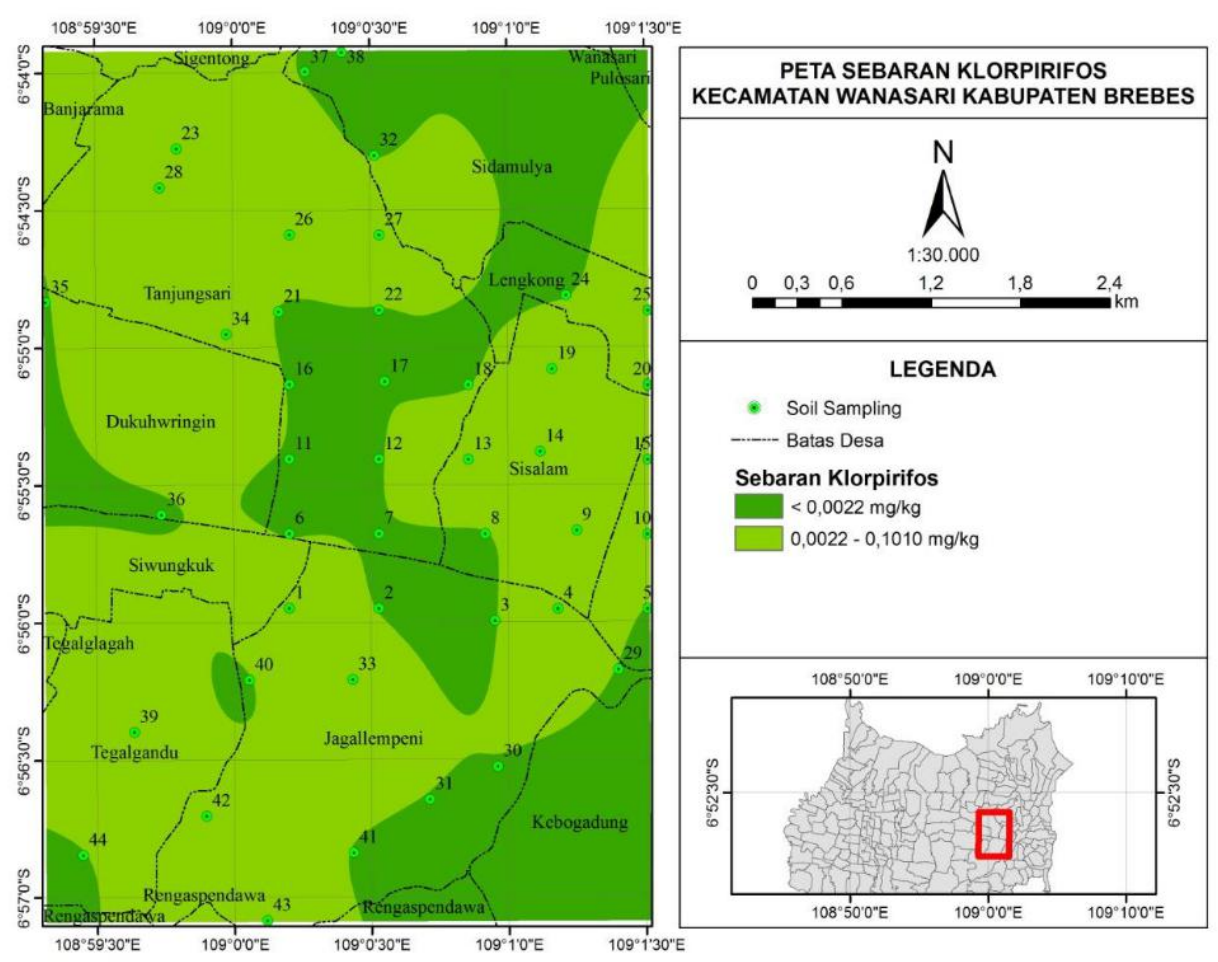

Figure 1. Distribution of chlorpyrifos residues on shallot farmland in Wanasari Sub-district, Brebes Regency, Indonesia. 2020 


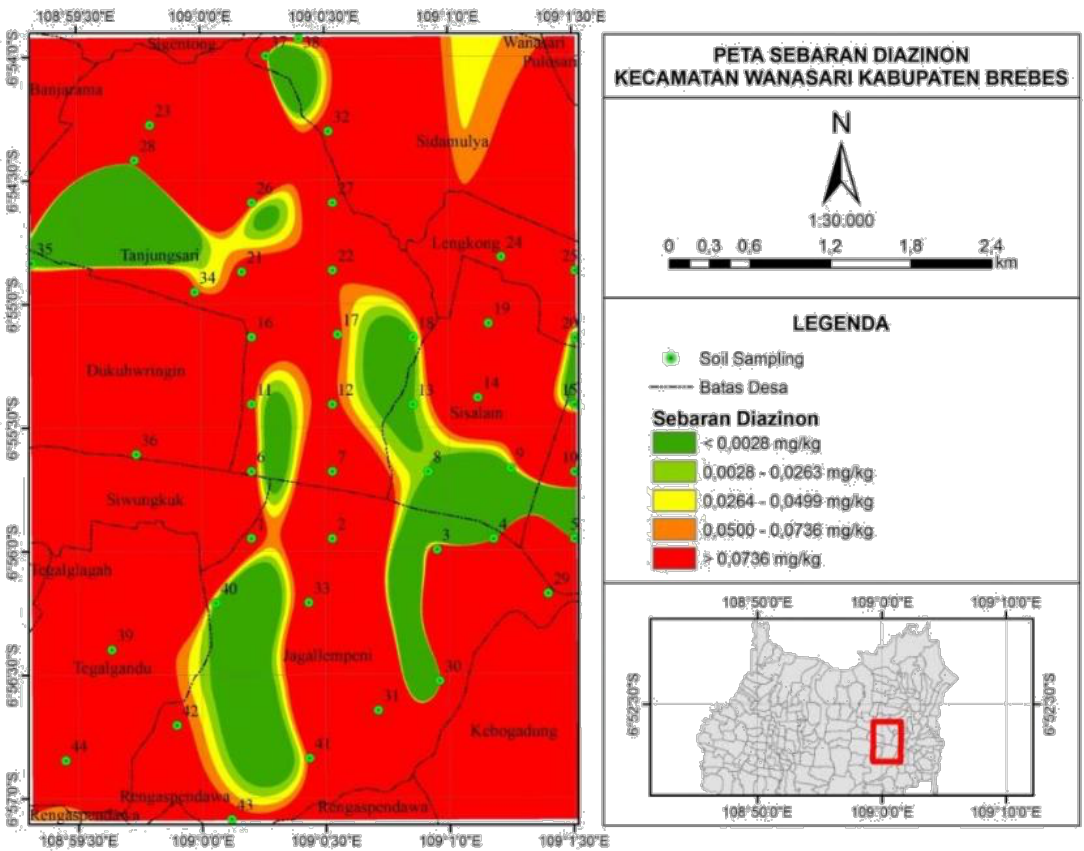

Figure 2. Distribution of Diazinon residues on shallot farmland in Wanasari District, Brebes

Regency, Indonesia. 2020

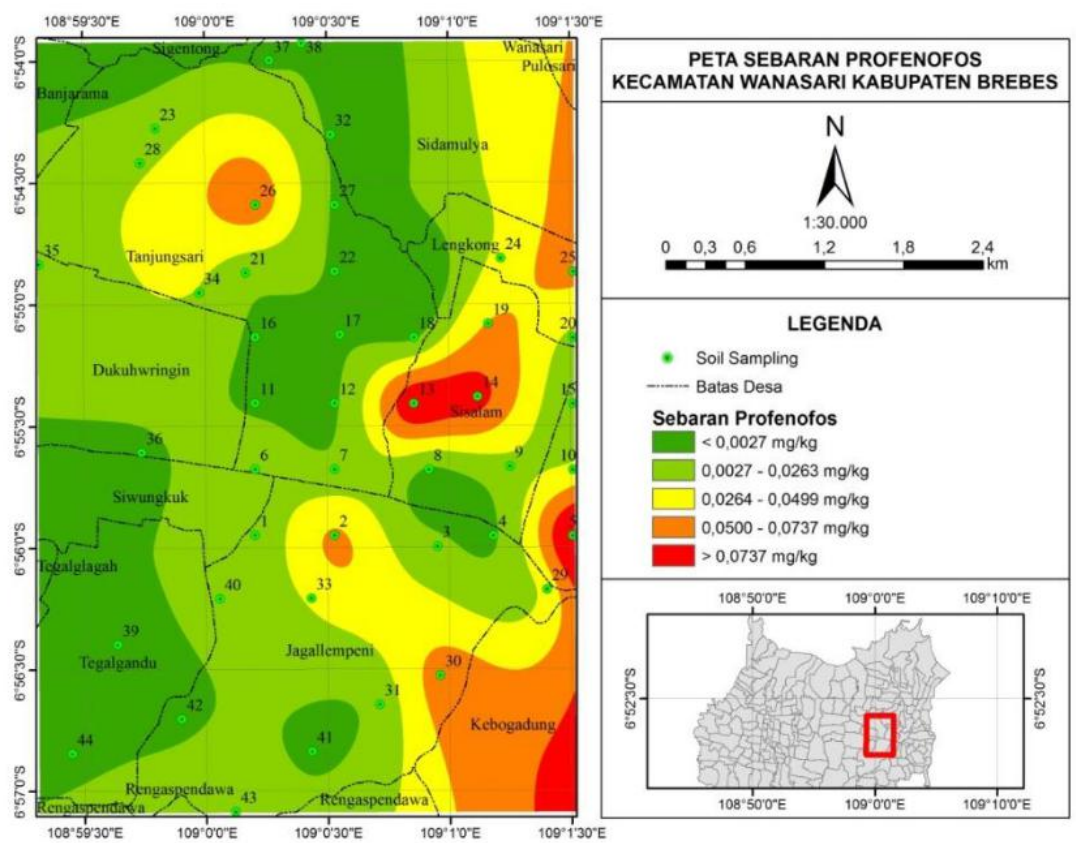

Figure 3. Distribution of Profenofos residues on shallot farmland in Wanasari District, Brebes Regency, Indonesia. 2020 
The geospatial model of Profenofos residues can be seen in Figure 3, that the distribution of Profenofos residues is not identified very low categories $(<\mathrm{LoD})$ there are 17 sampling points, 15 low categories are identified 15 points, the medium category is identified at 4 points, high category there are 3 points and very high categories 5 point. There are 8 points whose values exceed MRL (0.0509 mg/ kg-0.0919 mg/ kg). Previous studies were identified as being $0.01 \mathrm{mg} / \mathrm{kg}$ in Kersana sub-district, whereas in Wanasari Sub-district were less than $0.01 \mathrm{mg} / \mathrm{kg}$ [13].

\section{Conclusions}

The research on the geospatial model of organophosphate insecticide residues (chlorpyrifos, diazinon, and profenofos) detected almost all three types of those organophosphate residues. Diazinon residue showed the highest distribution, out of 44 points with a value above MRL, there were 34 points which diazinon can be detected. Hence, in the geospatial model, diazinon mainly indicated by the red color. Chlorpyrifos was detected at the level of $<$ LoD-0.0949 mg / kg, Diazinon found at the level of $<$ LoD-28.1732 mg / kg, and Profenofos was at the level of $<$ LoD- $0.0919 \mathrm{mg} / \mathrm{kg}$.

\section{Acknowledgment}

Thank you to the Agricultural Instructor of Wanasari Sub-district, Brebes regency, Head of Indonesia Agriculture Envirenment Research Institute (IAERI), IAERI Integrated Laboratory Staffs, Head of CoREM Laboratory, and the staffs of CoREM Laboratory, Semarang-Indonesia, for assisting in completion of this research.

\section{References}

1. BPS-Statistics Indonesia, Statistics of Seasonal Vegetables And Fruiits Plants, Indonesia. BPS-Statistic Indonesia. ISSN: 2088-8392 (2018)

2. Badan Pusat Statistik, Brebes dalam angka tahun 2017. Badan Pusat Statistik Kabupaten Brebes (2018)

3. www.pertanian.go.id, Indonesia kembali Eksport Bawang Merah ke Thailand 5.600 ton. Diakses 12 Juli 2020

4. Badan Pusat Statistik (BPS), Brebes dalam angka tahun 2018. Badan Pusat Statistik Kabupaten Brebes (2019)

5. Fernandez-Cornejo, J., R. Nehring, C. Osteen, S, Wechsler, A. Martin, A. Vialou. Pesticide Use in U.S. Agriculture: 21 Selected Crops, 1960-2008. Economic Information Bulletin No. EIB-124 (2014)

6. Yadav, I.C., N. L. Devi. 2017. Pesticides Classification and Its Impact on Human and Environment. Environ. Sci. \& Engg. Vol. 6: Toxicology, 140-158.

7. Ardiwinata dan Nursyamsi, Residu Pestisida di Sentra Produksi padi di Jawa Tengah. Jurnal Pangan 21(1), 39-58 (2012)

8. Vera S, Hans GJ Moil , P. Zomer, M. Tienstra, Coen J. Ritsema, Violette Geissen. Pesticide residues in European agricultural soils - A hidden reality unfolded. Science of The Total Environment 653 1532-1545(2019)

9. Mensah F, B.Yayra, E.D. Okoffo, G. Darko dan C. Gord. Organophosphorus pesticide residues in soils and drinking water sources from cocoa producing areas in Ghana. Environmental systems research 5(10) (2016) 
10. Harsanti, E.S, Martono E., H.A. Sudibyakto dan Sugiharto E. Residu Insektisida Klopirifos dalam Tanah dan Produk Bawang Merah Allium ascalonicum L, di Sentra Poduksi Bawang Merah di Kabupaten Bantul, Yogyakarta (2015)

11. Wahyuni, S, Indratin, A.N. Ardiwinata, Kontaminasi Residu Organofosfat dalam Darah Petani di Kabupaten Indramayu Jawa Barat(2018)

12. Joko T, Pola Sebaran Residu Pestisida Organoklorin dan Organofosfat dengan Analisis Geospasial di Lingkungan Tanah Pertanian Bawang Merah (Allium cepa L.)Kecamatan Wanasari kabupaten Brebes. Disertasi Progran studi Doktor ilmu lingkungan Sekolah pasca Sarjana Universitas Diponegoro(2018)

13. Nining E, R.S.Sjaiful Nazli, Zaenal Alim, Mas'ud, Machfud, Sobir. Profil Residu Insektisida Organofosfat di Kawasan Produksi Bawang Merah (Allium Ascolonicum L) Kabupaten Brebes Jawa Tengah. Journal of Natural Reseorces and Environmental management 9(4):999-1009 (2019)

14. Suganda H, Achmad Rahman dan Sutono. Petunjuk pengambilan contoh tanah.Balittanah@litbang.pertanian.go.id. Halamam 1-21 (diakses tanggal 17 Juli 2020)

15. Hou, Xue.,Mei Han, Xion Hang Dai, Xiao Feng Yang, Sheng gou. A multiresiue method for the determination of 124 pesticides in rice by modified QuEChERS extraction and gas chromatography-tandem mass spectrometry, Food Chemistry 138 1198-1205 (2013)

16. Komisi Pestisida. Metode Pengujian Residu Pestisida dalam Hasil Pertanian. Jakarta: Departemen (1997)

17. M.Helmi, A. Satriadi, A. A. Dwi Suryoputro, J. Marwoto, H. S. Hariyadi. Rehabilitation Priority Area Assessment on Death Coral Using Cell Based Modeling Approach at Parang Island, Karimunjawa National Park, Indonesia.International Journal of Civil Enginering and Technology (IJCIET) Volume 9, Issue 11 November pp 2949-2961 (2018)

18. Sudirman N, M. Helmi dan N. Susetyo Adi. Modeling mangrove 'blue carbon' ecosystem service in Jakarta bayas an impact of coastal development. E3S Web of Conferences : Environmental Policy, Planning and Education The $2^{\text {nd }}$ International Conferences on Energy, Environmental and Information System Volume :73 04023 (2018) p1-5. https://doi.org/10.1051/e3sconf/20187304023. ICENIS (2018)

19. M. Helmi, Y. H. Pholandani, H. Setiyono, A. Wirasatriya, W. Atmodjo, R. Widyaratih, A. A. Dwi Suryoputro. Intergrated Approach Of Tsunami Vulnerability Assessment At Coastal Area Of Kalianda Sub District, South Lampung District, Lampung Province, Indonesia. International Journal of Scientific \& Technology

20. Research Volume 9, Issue 03, March 2020. ISSN 2277-8616 p1804-1808 (2020)

21. I. G. A. Kusdiah Gemeliarini, M. Helmi. Earthquake Capacity Assessment Based on Geospatial Model At North Lombok, West Nusa Tenggara. E3S Web of Conferences 73, 0 (2018). ICENIS (2018)

22. B. R. Fitriyantoa, M. Helmi, Hadiyanto. Analyzing spatiotemporal types and patterns of urban growth in watershed that flow into Jakarta Bay, Indonesia. Remote Sensing Applications: Society and Environment 14 (2019) 170-177. Science Direct (2019)

24. Mutaqin B,W., M A Marfai, M Helmi, M G Rindarjono, R Windayati, Sunarto. SpatioTemporer mamping of ecotorism activities in Buleleng conservation zone: $A$ methodological review. The 3rd Environmental Resources Management in Global Region. IOP Conf. Series: Earth and Environmental Science 451 (2020) 012095.IOP Publishing.doi:10.1088/1755-1315/451/1/012095 (2020)

25. Thomas Triadi Putranto, TRN Amanah, B. Warsito, H. Purnaweni and M. Helmi. Multivariate statistical analysis for The Asessment og Groundwater Quality in Semarang Low Land Area. International Journal of GEOMATE, Feb., 2020, Vol.18, 
Issue 66, pp.124-131 ISSN: 2186-2982 (P), 2186-2990 (O), Japan, DOI: https://doi.org/10.21660/2020.66.36760 (2020)

26. M. Helmi, Purwanto, W. Atnojo, P.Subardjo, A.Aysira. Benethic Diversity mapping and SEacape Ecology Approach at Parang Islands, Karimunjawa National Park, Indonesia. International Journal of Civil Engineering and Technology (IJCIET)Volume 9, Issue 11, November 2018, pp. 227-235, Article IJCIET_09_11_023. IAEME Publication (2018)

27. Badan Standarisasi Nasional. Batas maksimum residu pada hasil pertanian. SNI 7313:2008 (2008). Badan Standarisasi Nasional (2008)

28. A. Irsadi, S. Anggoro, T. R. Soeprobowati, M. Helmi, A. S. E. Khair. Shoreline and mangrove Analysis Along Semarang Demak, Indonesia for Sustainable Environmental Management. Jurnal Pendidikan IPA Indonesia JPII 8 (1) (2019)1-11 http://journal.unnes.ac.id/index.php/jpii (2019)

29. Pasaribu J.M. dan N. S. Haryani. Perbandingan Teknik Interpolasi dan DEM SRTM dengan metode Inverse Distance Weighted (IDW) Natural Neighbor dan Spline. Jurnal Penginderaan Jauh Vo. 9 No. 2 Desember 2012 :126-139 (2012)

30. Khoirul Anwar, M. R. Mustakananfola and M. Helmi. Spatial Analysis of Tsunami Threat Level in the Coastal of Jember Regency, East Java, Indonesia . Asian Jr. of Microbiol. Biotech. Env. Sc. Vol. 20, No. (4) : 2018 : 1153-1162. Global Science Publications. ISSN-0972-3005 (2018)

31. Dorijan Radocaj, M. Jurisi, V. Zebec and I. Plas. Delineation of Soil Texture Suitability Zones for Soybean Cultivation: A Case Study Continental Croatia. Agronomy2020, 10, 823: doi:10.339/agronomy10060823. www.mdpi.com/journal/agronomy (2020)

32. T.P. Robinson, G. Metternicht. Testing the performance of spatial interpolation techniques for mapping soil properties. Computers and Electronics in Agriculture 50 (2006) 97-108. www.elsevier.com/locate.compag (2006) 